\title{
РОЛЬ ДУХОВНО-ІНТЕЛЕКТУАЛЬНОГО РОЗВИТКУ ОСОБИСТОСТІ В РОБОТІ ПРАВОЗНАВЦІВ
}

\author{
Черновол-Ткаченко P. I. \\ кандидат педагогічних наук, професор, директор Інституту підвищення \\ кваліфікації педагогічних працівників і менеджменту освіти, \\ Харківський національний педагогічний університет \\ імені Г. С. Сковороди,м. Харків, Україна

\section{Фідясва Т. С.} \\ здобувачка третього (освітньо-наукового) рівня вищої освіти кафедри \\ початкової та професійної освіти, Харківський національний педагогічний \\ університет імені Г. С. Сковороди, м. Харків, Україна \\ У статті зазначено визначальну роль духовно-інтелектуального \\ розвитку особистості в роботі правознавців. Уточнено, щзо духовно- \\ інтелектуальний розвиток правознавиів виявляється у вільному ви- \\ борі способів професійної діяльності, побудові стратегї особистіс- \\ ного й професійного зростання, формуванні наукового світогляду. \\ Ключові слова: правознавці, розвиток, інтелектуальні вміння, \\ креативне навчання. \\ The article notes the decisive role of spiritual and intellectual development \\ of the individual in the work of jurists. It is specified that the spiritual and \\ intellectual development of jurists is manifested in the free choice of ways \\ of professional activity, the construction of a strategy of personal and \\ professional growth, the formation of a scientific worldview. \\ Key words: urists, development, intellectual skills, creative learning.
}

Правознавці у своїй професійній діяльності мать справу з населенням, котре останнім часом дуже схвильоване, подавлене, пригнічене різними негативними факторами. Будемо солідарні з ученою I. Булах [2] у тому, що суспільство вражене багатьма негараздами. Конкуренція політичних партій, боротьба між ними, що призводить до негативної реакції духовно-інтелектуальних людей, здатних реалізовувати власний потенціал у сприятливих умовах праці й життя. До правознавців звертаються за допомогою люди, котрі незадоволені умовами життя, особливо тоді, коли існує соціальна несправедливість у суспільстві. Нині гострим є питання самозбереження особистості, оскільки не кожна людина має змогу отримати кваліфіковану допомогу й лікування в умо- 
Розділ І. Ціннісні орієнтири духовно-інтелектуального виховання, розвиток духовно-інтелектуальних якостей особистості в умовах співпраці й інклюзії

вах пандемії. У складних умовах, у тому числі й військовому протистоянні, зростає невпевненість і агресивність з боку тих людей, які найбільше постраждали та їм не надали своєчасної допомоги. Зазначимо, що з огляду на вище сказане, питання духовно-інтелектуального розвитку особистості є актуальними в роботі правознавців.

Дотичними науковими працями є такі, в яких йдеться про значущість моральних імперативів для психологічної науки та освітянського простору (І. Булах), духовний саморозвиток особистості у контексті вітчизняного державотворення (Ю. Калиновський, С. Мануйлов), сучасні підходи до навчання студентів-правознавців у закладах вищої освіти ( О. Чижикова).

Мета статті - розкрити роль духовно-інтелектуального розвитку особистості в роботі правознавців.

Нам імпонує думка Ю. Калиновського та Є. Мануйлова [1] про духовний саморозвиток особистості, який відбувається у нормативноціннісній системі координат, утверджується культурними й державотворчими практиками, зокрема в нашій країні. Як зазначають цитовані вчені, у демократичних державах людина отримує більше свободи для самовираження й ціннісного вибору, порівняно $з$ авторитарними та тоталітарними системами. 3 огляду на сказане, маємо думати про те, що духовно-інтелектуальний розвиток особистості має виявлятися у вільному виборі способів професійної діяльності, побудові стратегії особистісного й професійного зростання, формуванні наукового світогляду.

У роботі правознавців роль духовно-інтелектуального розвитку особистості є визначальною і стратегічною для виконання професійних обов’язків. Духовність виявляється в сприйнятті потреб іншої людини, розуміння іiі труднощів і непередбачених ситуацій, причин розгубленості та розчарування. Інтелектуальні вміння допомагають проаналізувати події, знайти логіку мислення й установити причинно-наслідкові зв'язки.

У науковій праці О. Чижикової [3] ужито термін «креативне навчання майбутніх правознавців». Цілком погоджуємося в тому, що успішний правознавець має бути підготовленим за новими педагогічними й професійними технологіями, в тому числі й креативними. У свою чергу, креативність є рисою духовної та інтелектуальної людини. У межах дослідження корисними є шляхи реалізації креативно- 
го навчання майбутніх правознавців, а саме: здійснення творчого підходу до розв'язання освітніх завдань і професійних ситуацій; розвиток креативності як особистісно-професійної якості майбутніх правознавців; активізація творчої активності та ініціативності учасників освітнього процесу; застосування інноваційних методів навчання - методу проєкту, симуляції, тренінгів, ігрових методів; зміна ролі викладача від керівника до партнера і співрозмовника, координатора, помічника; організація взаємодії і співпраці; сприяння прояву творчого ризику, інновацій та уяви.

Отже, духовно-інтелектуальний розвиток правознавців виявляється у вільному виборі способів професійної діяльності, побудові стратегії особистісного й професійного зростання, формуванні наукового світогляду.

\section{Список використаних джерел:}

1. Булах I. С. Значущість моральних імперативів для психологічної науки та освітянського простору. ПРАВНИЧО-ПОЛІТОЛОГІЧНІ ТА ІСТОРИЧНІ СТУДІЇ ПРОБЛЕМ УКРАЇНСЬКОГО ДЕРЖАВОТВОРЕННЯ : маТеріали Всеукраїнської науково-практичної конференції, 16 січня 2019 року; ред. кол. : В. П. Андрущенко, Ю. С. Шемшученко, О. О. Рафальський та ін. Київ : Вид-во НПУ імені М. П. Драгоманова, 2019. С. 267-270.

2. Калиновський Ю. Ю., Мануйлов Є. М. Духовний саморозвиток особистості у контексті вітчизняного державотворення. Проблеми саморозвитку особистості в сучасному українському соціумі : матеріали всеукр. наук.-практ. конф. (21 берез. 2019 р.) / НЮУ ім. Ярослава Мудрого. Харків : Право, 2019. 126 с.

3. Чижикова О. Сучасні підходи до навчання студентів-правознавців у закладах вищої освіти. Освітологічний дискурс. 2019. №1-2 (24-25). C. 161-72. 